\title{
Concentrations of heavy metals and PCBs in the tissues of European beavers (Castor fiber) captured in northeastern Poland
}

\author{
Kazimierz Zalewski • Jerzy Falandysz • \\ Monika Jadacka • Dorota Martysiak-Żurowska • \\ Bartosz Nitkiewicz $\cdot$ Zygmunt Giżejewski
}

Received: 25 January 2011 / Revised: 9 January 2012 / Accepted: 25 January 2012 /Published online: 23 March 2012

(C) The Author(s) 2012. This article is published with open access at Springerlink.com

\begin{abstract}
European beavers (Castor fiber) from two regions were examined to identify exposure to persistent environmental contaminants. A reference group was comprised of six animals from the Forest Division of Srokowo, and an exposed group was comprised of five animals from the vicinity of a former military airport operated in 1918-1986-both from Warmia land in Poland. ${ }^{137} \mathrm{Cs}$ in beavers' muscles was considered negligible for the overall condition and reproduction of the animals. Elevated levels of $\mathrm{Cd}$ and $\mathrm{Pb}$ occurred in the kidneys and liver of beavers from a former military airport area. dl-PCBs were found in the liver of all
\end{abstract}

Communicated by C. Gortázar

K. Zalewski $(\bowtie) \cdot$ B. Nitkiewicz

Department of Biochemistry, Faculty of Biology,

University of Warmia and Mazury,

Oczapowskiego 1a,

10-957 Olsztyn, Poland

e-mail:k.zalewski@uwm.edu.pl

J. Falandysz

Research Group of Environmental Chemistry,

Ecotoxicology and Food Toxicology, Institute of Environmental

Sciences and Public Health, University of Gdańsk,

80-952 Gdańsk, Poland

e-mail: jfalandy@chem.univ.gda.pl

D. Martysiak-Żurowska

Department of Food Chemistry, Technology and Biotechnology,

Gdańsk University of Technology,

80-233 Gdańsk, Poland

e-mail: domazu@wp.pl

M. Jadacka $\cdot$ Z. Giżejewski

Institute of Animal Reproduction and Food Research,

Polish Academy of Sciences,

10-718 Olsztyn, Poland

e-mail: m.jadacka@pan.olsztyn.pl

e-mail: Gizejewski@wp.pl specimens, and pCB no. 118 was a dominant compound. Beavers as animals living both in water and land habitats can be good bioindicators of heavy metal environmental pollution caused by human activity. Despite the significant contamination of former military sites in northeastern Poland, the beaver population shows an upward trend, reflecting the excellent adaptation of this species to a changing environment.

Keywords European beaver (Castor fiber) - Heavy metals . Planar PCBs

\section{Introduction}

The global economic development leads to environmental pollution with numerous persistent compounds while exposure to some of them, e.g., heavy metals $(\mathrm{Cd}, \mathrm{Hg}, \mathrm{Pb}, \mathrm{Cu}, \mathrm{Zn}$, $\mathrm{Cr}$ ), continues worldwide. Production and use of certain toxic and persistent organic compounds, e.g., polychlorinated biphenyls (PCBs), were banned (Falandysz 2007). The toxic impacts of heavy metals and persistent organic compounds relate both to acute and chronic effects and those that are chronic are more common (Coggins et al. 2006).

Animal populations reflect the health of the overall environment and are used as bioindicators while evaluating food safety (Food and Drug Administration 1993). Both domestic and wild species, including raptors and big game animals, have been successfully used as bioindicators of environmental pollution (Corsolini et al. 2000; Jorhem et al. 1991; Pokorny and Ribaric-Lasnik 2009; Szkoda and Żmudzki 2001; Szymczyk and Zalewski 2001).

Warmia and Mazury land in the northeastern region of Poland is largely a farmland, forestry, and great lakes region 
that is away from heavy industry and urbanization. Nevertheless, due to the past use of organochlorine pesticides in agriculture and/or global atmospheric circulation, the compounds such as HCBs, DDTs, HCHs, CHLs remain as ultratrace contaminants detected in wildlife and foods (Falandysz and Kannan 1992). Plant biomass from forests in Poland contains certain amounts of highly toxic and persistent PCBs, polychlorinated naphthalenes, polychlorinated dibenzo- $p$ dioxins, and polychlorinated dibenzofurans due to local and global sources (Bochentin et al. 2007; Falandysz et al. 2012; Orlikowska et al. 2009).

$\mathrm{Cd}, \mathrm{Cu}$, and $\mathrm{Zn}$ were considered as risk factors to certain beaver (Castor fiber) populations in Europe (Fimreite et al. 2001; Nolet et al. 1994). In Polish beavers, some perfluorinated compounds were found as contaminants (Falandysz et al. 2007), but knowledge on their exposure and risk to many popular environmental contaminants is lacking.

After World War II, the beaver was a rare species in Europe. An increase in the beaver population size has been noted since the 1970s due to effective reintroduction and protection. Other factors that contributed to the abundance of beavers in Poland include a decrease in consumer demand for fur products and the construction of industrial and municipal wastewater treatment plants, which improved environmental quality. Today, there are approximately 2,230 beaver colonies in northeastern Poland. The total beaver population in this region, estimated at around 7,500-8,000 animals, is the largest in the country.

The main aim of this study was to assess exposure to $\mathrm{Cd}$, $\mathrm{Pb}, \mathrm{Zn}$, and $\mathrm{Cu}$ and dioxin-like PCBs (dl-PCBs) and radiocesium $\left({ }^{137} \mathrm{Cs}\right)$ of European beavers inhabiting the "Beaver Mainstay" reserve that is under the direct influence of surface and groundwater inflowing from a contaminated former military airport (operated in 1918-1986) area in Warmia land in northeastern Poland.

\section{Materials and methods}

Animals

Two groups of beavers of reproductive age were captured between 20 February and 5 March 2003 in the district of Olsztyn. One group (exposed animals) consisted of three males and two females from the Beaver Reserve on the Pasłęka river, situated in the close neighborhood of a former military airport and located at $54^{\circ} 06^{\prime} \mathrm{N}, 20^{\circ} 07^{\prime} \mathrm{E}$. A second (reference) group consisted of six males captured in the Forest Division of Srokowo near the town of Ketrzyn. The number of animals available for research by license was relatively low because beavers are strictly protected and are listed in the Red Book of Threatened Species of Poland (IUCN 2008). Beavers were captured during the day using nets and in accordance with the legal regulations and permissions issued by the local Environmental Conservator (OSR/OIII/6636/16/2002) and the local Animal Ethics Committee $(1 / \mathrm{N} / 04.01 .2002)$. The animals were anesthetized with i.m. injection of $2.5 \mathrm{ml}$ xylazine (Xylazine $10 \%$, Biowet Puławy, Poland) at $2.5 \mathrm{~h}$ after capture. After $10 \mathrm{~min}$, they were administered i.m. with $1 \mathrm{ml}$ kethamine (Bioketan, Biowet Gorzow Wielkopolski, Poland). The animals were weighed on an electronic scale within an accuracy of $0.01 \mathrm{~kg}$, and the following measurements were taken: body length from the tip of the nose to the end of the tail, the length and width of the head, the circumference of the thorax, and the length and width of the tail. The animals were bled and decapitated under full anesthesia. Twentygram samples of the biceps femoris muscle were taken with a scalpel. Liver samples of similar weight and the kidneys were collected immediately postmortem. The reproductive organs of the beavers were also collected for a fertility analysis described elsewhere (Bierła 2007).

Chemical analysis

\section{Heavy metals}

Samples were weighed (about $1 \mathrm{~g}$ ) in PTEE (Teflon) vessels, and $5 \mathrm{ml}$ of concentrated $\mathrm{HNO}_{3}$ was added. After predigestion at room temperature overnight, the samples were digested in closed vessels in an Automatic Microwave System. Then, the samples were transferred to a 50-ml volumetric flask and diluted with ultrapure water.

Metals were determined using validated methods by inductively coupled plasma-mass spectrometry (PerkinElmer Elan 5000) using the external standard method with indium as an internal standard or with an inductively coupled plasma double focused high-resolution mass spectrometer Plasma Trace (VG Elemental, UK) equipped with an ultrasonic nebulizer USN (Applied Research Laboratories, Switzerland).

\section{Radiocesium}

${ }^{137} \mathrm{Cs}$ was determined in beavers' muscles by gamma spectrometry (Pietrzak-Flis and Krajewski 1994).

\section{Polychlorinated biphenyls}

dl-PCBs were determined by isotope dilution and capillary gas chromatography coupled to high-resolution mass spectrometry (HRGC/HRMS). Isotope labeled $\left({ }^{13} \mathrm{C}_{12}\right)$ non and mono-ortho chlorobiphenyl congeners were used as internal standards (PCB mixture-EC-4937). Details of PCB determination (extraction, cleanup and fractionation, multi-layer silica gel cleanup step, alumina layer cleanup and fractionation step, 
hypercarb-HPLC fractionation of sub-step, and PYE-HPLC fractionation of sub-step) have been described previously (Hanari et al. 2004).

\section{Statistical procedure}

For all statistical procedures, STATISTICA 8.0 was used. Results were expressed as mean and standard deviation (SD). The difference was considered significant if $p$ was below 0.05 .

\section{Results and discussion}

Animals

The captured European beavers were examined in detail, including individual traits such as coloring, body weight, and body measurements. Based on the results, it was concluded that their body weight ranged from 13.29 to $23.94 \mathrm{~kg}$, and it was correlated with body length and other measurements. The smallest animal was beaver 2 and the largest-beaver 8. In general, beavers from the Forest Division of Srokowo were larger and in better physical shape than those captured on the Pasłekka river. The most obese individuals were beavers 11 and 10 .

\section{Radiocesium}

The ${ }^{137} \mathrm{Cs}$ content of muscles was low, below the detectability level in some animals (Table 1).

\section{Heavy metals}

The highest concentration of cadmium in beavers captured in Warmia and Mazury was found in the kidneys (from 0.47 to $12.43 \mathrm{mg} / \mathrm{g}$ fresh weight), whereas much lower levels were observed in the liver. The muscles of all beavers contained negligible quantities of cadmium. The cadmium content of all analyzed tissues of animals inhabiting the area in the vicinity of a former military airport was higher than in the control group (beavers captured in the Forest Division of Srokowo) over threefold in the kidneys. Despite differences in the cadmium content of tissues between animals, cadmium had no significant effect on their condition.

The obtained results relating to the content of cadmium in the European beaver (Table 1) are similar to the percentage of this element in the tissues and organs of European beavers in Norway. Fimreite et al. (2001) studied a large population of beavers (92 animals) and reported the following cadmium concentrations in their tissues, as compared with our findings (micrograms per gram fresh material, FM): liver-1.03/0.58, kidneys-10.25/7.097,

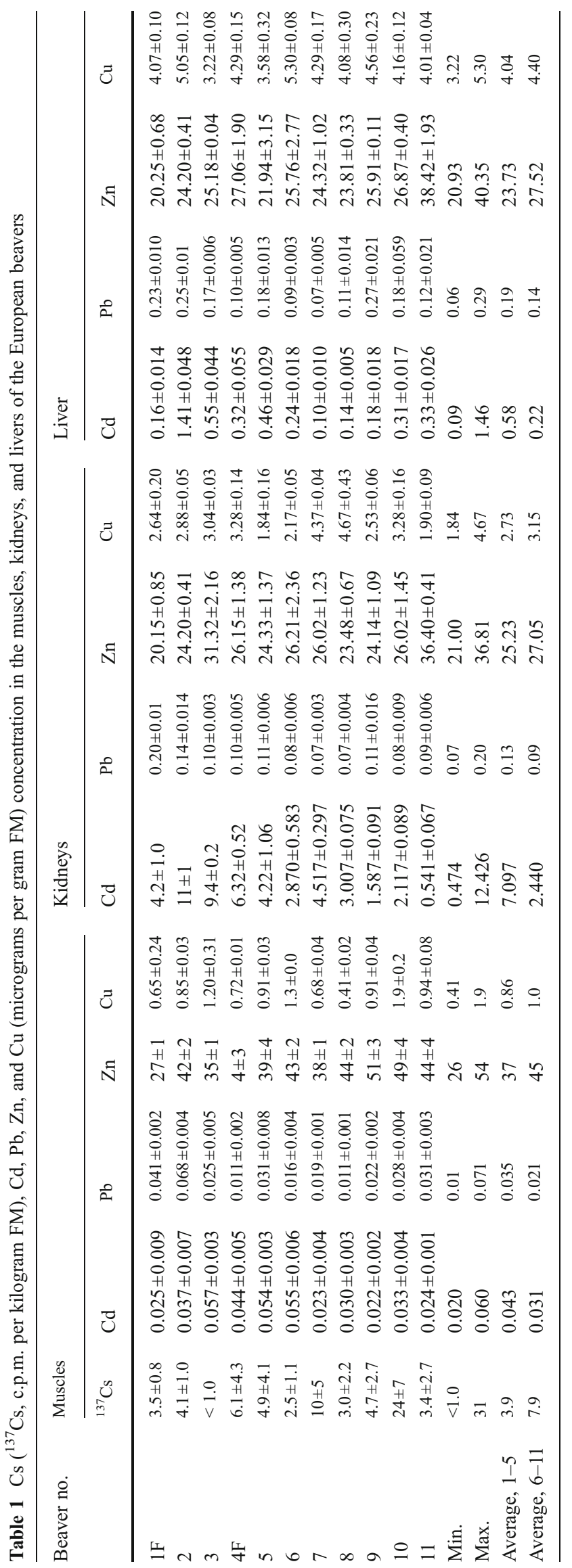


and muscles $-0.06-0.043$. Similar values were observed in the tissues of fish in northern Luxembourg (Boscher et al. 2010) and in the tissues of otters in Hungary (Lanszki et al. 2009). The highest concentration of cadmium in the kidneys of herbivorous animals was observed in European beavers captured on the Mulde river in Germany $-467 \mathrm{mg} / \mathrm{kg}$ dry matter, i.e., $93.4 \mu \mathrm{g} / \mathrm{g}$ fresh tissue weight (Nolet et al. 1994).

In the light of Polish and European Union legal standards for animal products, the maximum allowable cadmium content is $0.05 \mathrm{mg} / \mathrm{kg}$ for muscles, $0.5 \mathrm{mg} / \mathrm{kg}$ for the liver, and $1 \mathrm{mg} / \mathrm{kg}$ for the kidneys of mammals and poultry. According to Table 1, the $\mathrm{Cd}$ content of muscles was minimally higher than the above standards in only three beavers, while the $\mathrm{Cd}$ concentration in the kidneys was very high, particularly in beavers 2, 3, and 4 captured in the Beaver Mainstay in the close neighborhood of a former military airport. Statistical analysis (Student's $t$ test) showed that the content of $\mathrm{Cd}$ in the kidneys is statistically significantly higher than the control group measurement.

Cadmium also induces changes in the concentration of sex hormones. It has a particularly profound effect on androgens, which play an important role in prostate cancerogenesis and acute testicular necrosis (Zeng et al. 2003). In the testicles, cadmium induces the production of high quantities of free radicals which causes morphological changes, such as damage to the seminiferous epithelium of sperm tubules and spermatogenesis problems (Oteiza et al. 1999). A detailed evaluation of spermatogenesis was presented by Bierla et al. (2007) who identified 27 morphological categories, of which only 12 were recognized as healthy sperm. The authors presented various sperm forms in the beavers examined in this study. The highest quantity of abnormal sperm $(58.5 \%)$ was observed in beaver 5 . In the other animals, the share of abnormal sperm ranged between $33 \%$ and $47 \%$, reaching the lowest level in beaver 2 (Bierła
2007). It is interesting that the testes of non-scrotal mammals, for example Suncus murinus (Insectivora, Soricidae), are cadmium resistant. Dragen and McAllister (1970) proved that s.c. injections of $\mathrm{CdCl}_{2}$ had a less significant impact on seminiferous tubule diameter in the shrew than in the mouse. According to these authors, the temperature differential between the rectum and cremaster sac in shrews is considerably lower than the rectal scrotal differential in mice. It has not been proved yet, but it is also highly possible in the case of beavers. Nonetheless, the above results do not support a clear conclusion due to the absence of research making a reference to beaver populations in other regions.

The high cadmium content of beaver kidneys could be explained by a high concentration of cadmium in their food in the autumn and winter (Brekken and Steinnes 2004; Fimreite et al. 2001; Hillis and Parker 1993; Kalas and Lierhagen 1992; Madland 1997; Nolet et al. 1994).

In comparison with cadmium content, a similar concentration of lead was observed in beaver muscles, but in the kidneys and liver, it was several times lower than $\mathrm{Cd}$ content (Table 1). The lead content of the tissues of beavers captured in the Beaver Mainstay was higher in comparison with animals of the control group. The discrepancies in the results obtained for every individual were very high, reaching up to $300 \%$ in the liver and more than $400 \%$ in muscles. The copper content of the liver ranged from 3.25 to $5.32 \mu \mathrm{g} / \mathrm{g}$ FM, and the average content in both analyzed groups was similar, also in the kidneys and muscles (Table 1).

Zinc concentration in the muscular tissue of the beavers ranged from 27.13 to $50.59 \mu \mathrm{g} / \mathrm{g}$ of fresh tissue weight (Table 1). When compared with muscles, the kidneys and liver were characterized by lower $\mathrm{Zn}$ concentration per fresh weight unit. In the control group (beavers 6-11), zinc concentration was insignificantly higher than in beavers captured in

Table 2 Content of non- and mono-ortho planar chlorobiphenyls in the liver of the European beaver (picograms per gram wet weight)

\begin{tabular}{lcccccccccc}
\hline PCB no. IUPAC & Beaver 1F & Beaver 2 & Beaver 3 & Beaver 5 & Beaver 6 & Beaver 7 & Beaver 8 & Beaver 9 & Beaver 10 & Beaver 11 \\
\hline 81 & 0 & 0 & 0 & 11.3 & 84.1 & 22.6 & 29.5 & 9.2 & 37.9 & 16.0 \\
77 & 18.8 & 65.0 & 22.8 & 20.2 & 40.1 & 124 & 83.6 & 33.3 & 268.1 & 87.9 \\
123 & 2.3 & 19.8 & 14.7 & 19.5 & 6.2 & 36.6 & 57.8 & 7.0 & 41.2 & 10.7 \\
118 & 87.3 & 198.5 & 92.9 & 87.3 & 57.9 & 280 & 216 & 72.4 & 517.7 & 285 \\
114 & 0 & 4.2 & 3.5 & 1.8 & 2.2 & 10.2 & 4.3 & 0 & 14.2 & 4.2 \\
105 & 57.6 & 139.4 & 54.3 & 49.6 & 54.6 & 145.1 & 113 & 57.7 & 331 & 100 \\
126 & 9.8 & 7.4 & 9.8 & 16.7 & 106.1 & 5.9 & 10.2 & 0 & 8.1 & 5.4 \\
167 & 10.9 & 27.7 & 4.5 & 9.6 & 9.4 & 94.1 & 58.7 & 15.7 & 72.6 & 49.0 \\
156 & 19.3 & 58.9 & 12.7 & 17.2 & 20.6 & 136.2 & 103.2 & 36.8 & 255.9 & 95.3 \\
157 & 7.8 & 17.2 & 3.3 & 7.6 & 4.5 & 46.6 & 8.8 & 5.1 & 22.8 & 12.0 \\
169 & 4.2 & 0 & 0 & 6.2 & 10.6 & 1.6 & 1.6 & 0 & 2.1 \\
189 & 3.0 & 5.9 & 1.5 & 2.3 & 2.5 & 16.0 & 12.2 & 4.0 & 17.1 & 12.2 \\
$\Sigma$ & 221 & 533 & 201 & 249 & 399 & 919 & 699 & 241 & 1,589 & 678 \\
\hline
\end{tabular}


the military area. High zinc concentration in tree leaves, bark, and cambium is due to the intensive uptake of this element $\left(\mathrm{Zn}^{+2}\right)$ by both the root system and the leaves. Soil zinc deficiency was not reported in the area where beavers were captured, and the soil $\mathrm{pH}(5-6)$ supports the optimal availability of $\mathrm{Zn}$ ions for plants.

$\mathrm{Zn}$ concentration of $37-45 \mu \mathrm{g} / \mathrm{g}$ fresh weight in the muscles of beavers and a lower $\mathrm{Zn}$ content in the kidneys and liver are similar to the $\mathrm{Zn}$ concentration in the muscles and organs of other herbivores - the red deer and roe deer from the region inhabited by the examined beavers (Szymczyk and Zalewski 2001; Falandysz et al. 2005). A study of the tissues of herbivorous animals in central and southern Poland and in Germany in the 1990s provided similar results.

In view of the above results, the concentrations of zinc and copper in the tissues of beavers of both groups are comparable to the concentration of these elements in the tissues of other herbivores and do not pose a threat to the health of the studied animals.

\section{PCBs}

Data on dl-PCBs in the liver of beavers are given in Table 2.

Total dl-PCB concentration varied between 221 and $1,589.7 \mathrm{pg} / \mathrm{g}$ wet weight. Up to 12 different dl-PCBs were identified in livers and at greater concentration were found in older animals (nos. 10, 11, and 7) (Table 2).

In this study, the examined individuals in the reproductive age could be grouped into three categories (the age of animals being roughly approximated): young animals (over 2.5 years), animals in their prime (3 to 10 years), and older animals (over 11 years). Nevertheless, data on dl-PCBs in wildlife other than beavers in Poland are lacking. Also lacking are data on dl-PCBs in beavers outside of Poland. A recent study of pine needles (Pinus silvestris) collected across Poland showed low contamination with total PCBs of vegetation in the northeastern part of Poland - an area where the examined beavers live, i.e., reported concentration was $4.1 \mathrm{ng} / \mathrm{g}$ wet weight (ww) in Kudypy, $3.7 \mathrm{ng} / \mathrm{g}$ ww in Olecko, and $5.7 \mathrm{ng}$ PCBs/g ww in Pasłek sites, while in densely urbanized and industrialized regions of the country were up to $49 \mathrm{ng}$ PCBs/g (Falandysz et al. 2012).

\section{Conclusions}

It is highly possible that the greatest changes in sperm morphology, observed in beaver 5 , were caused by a relatively high content of $\mathrm{Pb}$ and $\mathrm{Cd}$ in the tissues and organs of this animal. The results of a detailed histopathological analysis of this beaver and the other ten animals were published in a doctoral dissertation (Bierła 2007). The conclusions formulated with respect to beaver 5 cannot be extrapolated to the entire population. Further investigations are needed with the involvement of animals inhabiting regions characterized by higher environmental contamination levels than Warmia and Mazury, e.g., beavers from Silesia. The tissues of all beavers captured in the vicinity of a former military airport contained substantially larger quantities of the above elements than the tissues of control group animals. The concentrations of zinc, copper, and radioactive cesium in the tissues of beavers of both groups, captured in northeastern Poland, were low and did not pose a threat to the health and reproduction of the animals. Beavers can easily adapt to changing environmental conditions, and therefore, they colonize new habitats across Poland.

Acknowledgments The study was partially financed by the Ministry of Science and Information Technology under grant no. 2PO4G09726 $(60 \%)$ and 0209.0806 (grant title: Evaluation of Xenobiotic Accumulation in Tissues of Male European Beavers (Castor fiber L.) and Characteristics of Changes it Induces in Spermatogenesis Parameters).

Open Access This article is distributed under the terms of the Creative Commons Attribution License which permits any use, distribution, and reproduction in any medium, provided the original author(s) and the source are credited.

\section{References}

Bierła JB (2007) Ph.D. thesis, University of Life Sciences-SGGW (Warsaw)

Bierła JB, Giżejewski ZK, Leigh C, Ekwall H, Söderquist L, Rodriguez-Martinez H, Zalewski K, Bred W (2007) Sperm morphology of the European beaver Castor fiber - an example of a rodent species with highly derived and pleiomorphic sperm populations. J Morphol 268:683-689

Bochentin I, Hanari N, Orlikowska A, Wyrzykowska B, Rostkowski P, Horii Y, Yamashita N, Falandysz J (2007) PCDD/Fs in pine needles of Poland. J Environ Sci Health Part A 42:1969-1978

Boscher A, Gobert S, Guignard C, Ziebel J, L'Hoste L, Gutleb AC, Cauchie H-M, Hoffmann L, Schmidt G (2010) Chemical contaminants in fish species from rivers in the north of Luxemburg: potential impact on the Uerasian otter (Lutra lutra). Chemosphere 78:785-792

Brekken A, Steinnes E (2004) Seasonal concentrations of cadmium and zinc in native pasture plants: consequences for grazing animals. Sci Total Environ 29:181-195

Coggins AM, Jennings SG, Ebinghaus R (2006) Accumulation rates of heavy metals: lead, mercury and cadmium in ombrotrophic peatlands in the west of Ireland. Atmos Environ 40:260-278

Corsolini S, Burrini L, Facrdi S, Lovari S (2000) How can we use the red fox as a bioindicator of organochlorines? Arch Environ Contamin 39:547-556

Dragen GL, McAllister H (1970) Biology of reproduction pp. 23-30

Falandysz J (2007) Dioxin-like compounds load of the bulk of Chlorofen - a technical chlorobiphenyl formulation from Poland. J Environ Sci Health Part A 42:1959-1968

Falandysz J, Kannan K (1992) Organochlorine pesticide and polychlorinated biphenyl residues in slaughtered and game animal fats from the northern part of Poland. Z Lebensm Unter Forsch Food Res 195:17-21 
Falandysz J, Szymczyk-Kobrzyńska K, Brzostowski A, Zalewski K, Zasadowski A (2005) Concentrations of selected heavy metals in the tissues of red deer (Cervus elaphus) from the region of Warmia end Mazury in Poland. Food Addit Contam 22:141-149

Falandysz J, Taniyasu S, Yamashita N, Rostkowski P, Zalewski K, Kannan K (2007) Perfluorinated compounds in some terrestrial and aquatic wildlife species from Poland. J Environ Sci Health Part A 42:1-5

Falandysz J, Orlikowska A, Jarzyńska G, Bochentin I, Wyrzykowska B, Drewnowska M, Hanari N, Horii Y, Yamashita N (2012) Levels and sources of planar and non-planar PCBs in pine needles across Poland. J Environ Sci Health Part A 47 (in press)

Fimreite N, Parker H, Rossel F, Hosen DA, Hovden A, Solheim A (2001) Cadmium, copper, zinc in Eurasian beaver (Castor fiber) from Bo, Telemark, Norway. Bull Environ Cont Tox 67:503-509

Food and Drug Administration (1993) Food and Drug Administration pesticide program: residue monitoring. J AOAC Int 77:135

Hanari N, Horii Y, Okazawa T, Falandysz J, Bochentin I, Orlikowska A, Puzyn T, Wyrzykowska B, Yamashita N (2004) Dioxin-like compounds in pine needles around Tokyo Bay, Japan in 1999. J Environ Monit 6:305-312

Hillis TL, Parker GH (1993) Age and proximity to local ore-smelters as determinants of tissue metal levels in beaver (Castor canadensis) of the Sundbury (Ontario) area. Environ Pollut 80:67-72

Jorhem L, Slorach S, Sundstrom B, Ohlin B (1991) Lead, cadmium, and mercury in meat, liver and kidney of Swedish pigs and cattle in 1984-1988. Food Add Contam 8:20-23

Kalas JA, Lierhagen S (1992) Terrestrisk naturovervåkning. Metallbelastninger i lever fra hare, orrfugl og lirype i Norge. In: 'Report no. 36 from Norwegian Institute of Nature Research
Lanszki J, Orosz E, Sug r L (2009) Metal levels in tissues of Eurasian otters (Lutra lutra) from Hungary: variation with sex, age, condition and location. Chemosphere 74:741-743

Madland HO (1997) Akkumulering av Kadmium I fjellrype. 'Thesis'. (Telemark University College)

Nolet BA, Dijakstra VAA, Heidecke D (1994) Cadmium in beavers translocated from the Elbe River to the Rhine/Meuse Estuary, and the possible effect on population growth rate. Arch Environ Contan Toxicol 27:154-161

Orlikowska A, Hanari N, Wyrzykowska B, Bochentin I, Horii Y, Yamashita N, Falandysz J (2009) Airborne chloronaphthalenes in Scots pine needles of Poland. Chemosphere 75:1196-1205

Oteiza PI, Adonaylo VN, Keen CL (1999) Cadmium-induced testes oxidative damage in rats can be influence by dietary zinc intake. Toxicology 137:13-22

Pietrzak-Flis Z, Krajewski P (1994) Radiocesium in diet and humans in northeastern Poland after the Chernobyl accident. Health Phys 67:115-120

Pokorny B, Ribaric-Lasnik C (2009) Lead, cadmium and zinc in tissues of roe deer (Capreolus capreolus) near the lead smelter in the Korska region (northen Slovenia). Contamin Toxicol 25:855-860

Szkoda J, Żmudzki J (2001) Distribution of lead and cadmium concentrations in pigs and bovine tissues in the last 30 years. Polish $\mathrm{J}$ Environ Stud 15:185-188

Szymczyk K, Zalewski K (2001) Content of copper, zinc, lead and cadmium in some tissues of red deer (Cervus elaphus) on Warmia and Mazury on 1999. Acta Pol Toxicol 9:105-114

Zeng X, Jin T, Zhou Y, Nordberg GF (2003) Changes of serum sex hormone levels and MT mRNA expression in rats orally exposed to cadmium. Toxicology 186:109-118 